\title{
Regional consensus gave birth to the modern public library
}

\author{
Renny Granda \\ Juan D Machin-Mastromatteo
}

This article was originally published as:

Granda, R. and Machin-Mastromatteo, J. D. (2015). Regional consensus gave birth to the modern public library.

Information Development, 31(3), 314-316. http://dx.doi.org/10.1177/0266666915577166

The final publication is available at: $\mathrm{http}: / /$ idv. sagepub.com/content/31/3/314

\begin{abstract}
In 1982, library experts from 30 Latin American and the Caribbean countries met in Venezuela to discuss the current state and development strategies for the region's public libraries. The result was the first technical-normative document for public libraries in the region, commonly known as the Caracas Declaration. This issue of Developing Latin America comments on the contents of this document, its influence and importance, and suggests the exercise of invoking and reviewing its principles and objectives to once again analyze the current state and project new development strategies.
\end{abstract}

Keywords: Latin America, development, public libraries, strategies, challenges and limitations

The 'Caracas Declaration for the Public Library as a Factor of Development and Instrument of Social Change in Latin America and the Caribbean' was the product of a consensus between experts from 30 countries in the region, reached during the Regional Meeting on the Current State and Development Strategies for the Development Public Library Services in Latin America and the Caribbean (UNESCO, CERLALC, IFLA and IABNSB, 1982), held in Caracas from 25-29 October 1982. The Declaration, which has its 33rd anniversary in 2015, was the first and among the most important technical-normative document for the public libraries of the region because it promoted the public library movement in Latin America and the Caribbean (LAC) by establishing a sense of direction for its development (Rodríguez, 2007). The Declaration was a regional agreement celebrated in the Venezuelan capital and supported by the United Nations Educational, Scientific and Cultural Organization (UNESCO), the Regional Center for the Promotion of the Book in Latin America and the Caribbean (CERLALC), the International Federation of Library Associations and Institutions (IFLA), and the Venezuelan National Library Autonomous Institute and Library Services (IABNSB). The Declaration contains the shared vision of the region's professionals at an historic moment: one which opened the door to wider views of social reality, democratic life, and regional integration. Hence, one of the first aspects it mentions is support to the main principles stated in the UNESCO Public Library Manifesto of 1972. The main needs of the region were compared with these principles, which were adapted to LAC reality in order to adopt them.

\section{The structure of the Caracas Declaration}

The Declaration is divided into three parts: 1) the principles that regional public libraries must follow, 2) the basic conditions to develop public libraries, and 3) recommendations for UNESCO Member States to establish public library systems from collaboration and cooperation. The first part enumerates eight principles for public libraries in the region, in order to assume commitment toward development, democracy and social change in LAC. According to Córdoba (1994), these principles "express the will of a library majority on what the public library should be in our countries. They defined to the necessary extent, the concept of public library that the practice has demonstrated to be viable" (para. 3). These principles also define the social function of the region's public libraries, which can be summarized as follows: 
1. Ensure free access to information which must be broad, current, and representative of the sum of different thoughts, in various formats.

2. Stimulate people's participation in national life, enhancing the role of the library as facilitator of social change and participation in democratic life.

3. Promote the understanding, dissemination, and defense of national indigenous and minority culture to assert cultural identity and the recognition and respect toward other cultures.

4. Promote the formation of critical, selective and creative readers through reading, thus training each individual to play an active role in society.

5. Support lifelong learning, eradicating illiteracy and supporting services for children, teenagers, neo-readers, and disabled readers, both social and physically.

6. Serve as information and communication centers for the community.

7. Develop national library services.

8. Support an economically strong and culturally independent national and regional editorial industry.

Álvarez and Gómez (2002) state that these were the eight essential premises that the LAC library discourse in the second half of the 20th century decided to address and assume. To summarize, these principles were related to: information access, social and democratic participation, cultural identity and diversity, reading promotion, education support, libraries as community information and communication centers, national library services, and the editorial industry. These components clearly show a social function for public libraries, a dimension that is still under construction. Córdoba (1994) highlights that the public library "is the one to serve the people from a community, thus playing a role in informal education, reading promotion, cultural rescue, and other [needs] demanded by the communities" (para. 3). Furthermore, Rodríguez (2007) points out that this document started to take into account "information services for the communities, reading promotion, services aimed toward special groups, as well as the awareness of the libraries' role in stimulating citizen participation in democratic life" (p. 16).

The Caracas Declaration emphasized the responsibility of the public library to stimulate the population's active participation, and its role as an instrument to facilitate social change and participation in democratic life. In this sense, the development of critical, selective and creative readers must continue to be one of the main actions of the public library (Alcaldía de Medellín, 2007).

The second part of the Declaration refers to the basic conditions for the development of public libraries in LAC, forming a vision that was closer and more realistic regarding the state of the LAC public library, stating the true needs or shortcomings, mainly institutional, which prevented (and in some cases, still prevent) the improvement of services in the region. The Declaration states the need of a legal framework to regulate the functions of the public library, contemplating state obligation to offer library services, national coordination, a system of services, normalization of technical processes, strategies for training human resources, and the sustainable endowment of services by assigning them specific budgets that are sufficient. The role of the state implies "the need of the libraries to be included in the development plans of each country" (Jaramillo, Álvarez and Moncada, 2005: 17). The Declaration closes with a series of recommendations to UNESCO Member States, urging them to: a) collaborate and cooperate toward the establishment of public library systems, b) pass a framework of laws and legal bases, c) include the eight principles in the countries' national development plans, d) organize governmental organizations specialized in library services, e) stimulate editorial production, reading promotion, and library planning, and f) support the training of appropriate human resources and increase the incentives for library workers, among other vital issues.

\section{The influence and importance of the Caracas Declaration}

The Declaration is an important document because it was written by professionals from the region and according to LAC needs and realities. Yepes (2007) comments that while the world has taken the UNESCO Public Libraries Manifesto, developing countries have the Caracas Declaration, which "seeks to build a public library that is more real for Latin Americans, that is a development factor and an instrument of social change" (p. 45). In fact, Rodríguez (2007) specifies that the principles of the Declaration "have been invoked and 
inserted in some statutes and regulations of regional libraries and library systems" (p. 16). We can track the influence of the declaration in diverse working documents and plans for the development of public library services, such as the National Network of Public Libraries of Colombia (Red Nacional de Bibliotecas Públicas, n.d.) and the Latin American and Caribbean Association of Public Libraries (sadly inactive), and it is still being mentioned many years after it was written, as in the case of the Medellín Pilot Public Library for Latin America (Alcaldía de Medellín, 2007). More than 30 years later, to invoke the Caracas Declaration can be an interesting exercise: to review its principles and objectives in comparing them to the current state of public libraries in this half of the second decade of the 21st century can provide some answers about LAC library work in each of our countries. In what ways have we created (or not) the basic conditions for our public library services to properly function and develop? Have we been able, in the last 30 years, to guarantee a legal framework, as well as appropriate funding, systemic integration, service diversity, and provide our libraries with qualified staff? In the same country that saw the writing of the Declaration, public libraries are at a very difficult stage, due in part to the social, financial and political crises that Venezuela is going through. It is hard to see public libraries which meet the minimal conditions of the Declaration because they have been forgotten by the State. We have libraries with scarce financial resources as well as limited and insufficiently qualified staff. Furthermore, there is an institutional structure that is sadly contaminated by the dominant party's political indoctrination. Political polarization greatly affects all aspects of this country's development, including any attempts at growing and developing further the already established public library system. However, there are notable cases in countries such as Colombia, Chile and Argentina, where they have recognized the importance of public libraries, which is translated into a larger presence of libraries in their respective legal frameworks, in their cultural and educational public policies, and even in their development plans and programs. It has been difficult for LAC public libraries to be understood, studied, observed, and even interpreted and recognized. They deserve to be redefined, updated, modernized, readjusted and pushed toward addressing the changes and challenges that have emerged during the last 33 years, and those that the future holds.

\section{References}

Alcaldía de Medellín (2007) Biblioteca Pública Piloto de Medellín para América Latina: Plan estratégico 2008-2018, versión 2. Available at: $\quad$ http://www.bibliotecapiloto.gov.co/documentos/acerca-de-la-bpp/plan-estrategicobpp/2014/plan_estrategico_bpp_2008_2018.pdf

Álvarez D, and Gómez J (2002) El discurso bibliotecario público sobre la lectura en América Latina (1950-2000): Una revisión preliminar con énfasis en Colombia. Revista Interamericana de Bibliotecología 1(25): 11-36. Available at: http://aprendeenlinea.udea.edu.co/revistas/index.php/RIB/article/view/7940/7442

Córdoba S (1994) La cooperación regional para el desarrollo social, cultural y bibliotecario. En: 60th IFLA Council and General Conference, Havana, Cuba, 21-27 August 1994. Available at: http://www.ifla.org/IV/ifla60/60-cors.htm

Jaramillo O, Álvarez D and Moncada D (2005) Políticas públicas para bibliotecas públicas: una propuesta de soluciones locales a problemas globales. Investigación Bibliotecológica 19(39): 13-27. Available at: http://www.ejournal.unam.mx/ibi/vol1939/IBIO3902.pdf

Red Nacional de Bibliotecas Públicas (n.d.). ¿Qué es la RNBP? Available at: http://www.bibliotecanacional.gov.co/rnbp/que-es-la-rnbp

Rodríguez G (2007) La biblioteca pública: análisis a manifiestos y directrices. Antioquia: Fondo Editorial COMFENALCO.

UNESCO, CERLALC, IFLA and IABNSB (1982) Informe Final [Caracas Declaration]. In: Reunión Regional sobre el Estado Actual y las Estrategias para el Desarrollo de los Servicios de Bibliotecas Públicas en América Latina y el Caribe, Caracas, Venezuela, 25-29 October 1982. Available at: http://unesdoc.unesco.org/images/0005/000525/052531SB.pdf

Yepes L (2007) Consideraciones políticas en torno a la biblioteca pública y la lectura. Antioquia: Fondo Editorial COMFENALCO. 